\title{
Analysis Of The Effect Of Brand Image On The Sales Volume Of Three Products
}

\author{
Nur Arifiya ${ }^{1}$ Aliffia Teja Prasasty ${ }^{2}$ dan Rina Nurhidayati ${ }^{3}$ \\ 1,2,3 Universitas Indraprasta PGRI Jakarta \\ Email Corespondent : arifiya87@gmail.com
}

\begin{abstract}
Brand image is one of the essential things that must be considered for maintaining the existence of a product. A positive brand image is expected to provide trust and satisfaction's consumer for the product. It will undoubtedly have an impact on increasing the number of product uses by the customer. The purpose of this study was to analyze the effect of brand image on product sales volume. The sampling technique in this study was random cluster sampling. Meanwhile, the analysis method used is Analysis of Variance (ANOVA). The results of the research that have been done show that there is an effect of brand image on sales volume. It can be a material consideration for the company to continue building a brand image to optimize product sales volume.
\end{abstract}

Keywords : Analysis of Variance, Brand image, Sales Volume

\begin{abstract}
Abstrak: Citra merk merupakan salah satu hal penting yang harus diperhatikan dalam mempertahankan eksistensi sebuah produk. Citra merk yang positif diharapkan dapat memberikan kepercayaan dan kepuasan kepada konsumen terhadap suatu produk. Hal ini tentu akan sangat berdampak pada peningkatan jumlah penggunaan produk oleh konsumen. Tujuan penelitian ini adalah untuk menganalisis pengaruh citra merk terhadap volume penjualan produk. Teknik pengambilan sampel pada penelitian ini adalah cluster random sampling. Adapun, metode analisis yang digunakan adalah Analysis of Varians (Anova). Hasil penelitian yang telah dilakukan, menunjukkan bahwa terdapat pengaruh citra merk terhadap volume penjualan. Hal ini dapat menjadi bahan pertimbangan bagi perusahaan untuk terus membangun citra merk, sehingga dapat mengoptimal volume penjualan produk.
\end{abstract}

Keywords : Anava, citra merk, volume penjualan 


\section{INTRODUCTION}

Business development in Indonesia has been growing rapidly, one of which is the business in laundry soap or detergent, so companies need to pay full attention to consumer needs to achieve success in selling their products. Today's detergent products are very diverse, each of which offers the advantages of its product. Starting in terms of quality, ability to clean stains, ability to retain color, and keeping the washing machine in good condition. Apart from these qualities, price is an equally important factor in determining consumers to buy a product. According to Kotler and Armstrong (2014), a consumer with a high level of involvement usually experiences five stages before making the purchase. These processes include identification of needs, information search, evaluation of alternatives, purchasing decisions, and finally, post-purchase behavior. In determining needs and this information will be closely related to the quality of a particular product. However, in the evaluation process, consumers will compare the prices and benefits obtained from several products with the same quality.

Based on this, each company will strive to keep its products salable in the market. One of the things that can be done is to build a brand image of the products produced. By knowing which product brands have quality and price that consumers can accept, the sales volume of these products will continue to dominate. Brand (brand) is a name, term, symbol, sign, design, or a combination of all that is used to identify products and differentiate the company's products from competitors' products (Muslichah, et al, 2011). According to Miftah (2018), brand image is the desired outcome of effective positioning is a distinct "position" (or image) that the brand occupies in the customer mind. Meanwhile, according to Kotler and Lane (2012), brand image is the consumer's hidden vision and belief, reflecting the association held in the consumer's mind.

According to Kotler and Amstrong (2014), product quality is the characteristics of a product or service that bear on its ability to satisfy stated or implied customer needs, which means that product quality is a characteristic of products and services support their ability to satisfy consumer needs. Hartini (2012) states two approaches to product quality: an objective approach to quality and subjective quality. The objective approach emphasizes the view of quality internally through the production and supply approach. While the subjective approach emphasizes the quality externally, namely the suitability of the resulting product with an external view, one of which is price suitability.

Based on the preceding, this study aims to see (1) the sales volume of 3 brands of detergent per day, (2) the sales volume per product, (3) there is an effect of brand image on sales volume per day.

\section{LITERATURE REVIEW}

\section{Brand Image}

Morhart, Malär, Guèvremont (2014) state that in order to engage in meaningful branding efforts, it is imperative for marketers to understand the nature of authenticity of their branded products and services, as well as its drivers and consequences. Both academics and practitioners therefore agree on the importance of authenticity for consumer behavior and branding. As Maurya and Mishra (2012) state that brands are omnipresent; they penetrate almost every aspect of our life: economic, social, cultural, sporting, even religion.

Kalieva (2015) "Brand" and "image"-are single, but not identical concepts. "Image" in relation to "brand" is perceived by the target audience as "a generalized portrait" of the branded object. The image-generating qualities are planned actions of the branded object, demonstrating them we can form public opinion.

Lee , James, Kim (2014) Brand image forms the basis for making better strategic marketing decisions about targeting specific market segments and positioning a product. Winarso (2012) Brand image is also regarded as a description of the offer of the company which includes the symbolic meaning associated customers through specific attributes of the products or services.

\section{Brand Image Importance}

As stated by Anwar, Gulzar, Sohail, Akram (2011), the brand effect is explained as the power of a brand to extract a highly positive response emotionally after its usage. Therefore, firms are creating strong brands to be one step ahead of their rivals in a fierce competition. Best brands stand for something. Symbols are the fastest form of communication from a brand to the consumer. They become more powerful with frequent use and are the most visible reminders of what the brand stands for.

A brand's identity must express the organization's unique mission, history, culture, values, and personality. Nike's logo was designed in 1971 and is an abstraction of a wing, after the Greek goddess of victory- Nike. This symbol gives the meaning to a company that markets running shoes and inspires consumers to "Just do it". 
According to Management study guide, MSG (2013) brand image is consumers' perception about the product and the organization's character; the brand image conveys emotional value, in other words it's not just a mental image. All in all, brand image is on the whole the impression in consumers' mind. "Brand image is the objective and mental feedback of the consumers when they purchase a product. Positive brand image is exceeding the customer's expectations. Positive brand image enhances the goodwill and brand value of an organization." (Management study guide, MSG 2013).

\section{RESEARCH METHOD}

This research is a quantitative which elaborated on the result of the difference in sales volume of 3 different brands of detergents, detergent brands that were observed in this study is Rinso, Daia, and easy. This method is quantitative because the research data is in numbers, and the analysis uses statistics. (Sugiyono, 2017). While the population, according to Sugiyono (2017), is "a generalization area consisting of objects/subjects that have certain qualities and characteristics that researchers apply to study and then draw conclusions." The population in this study were three different agents where agent one was located at Jl. Ampar 1 no. 84, agent two is located at Jl. Mampang prapatan X no. 27, and agent 3 is located at jl. Tegal parang utara IV no. 55. The samples of this study were three different detergent products, namely rinso, daia, and easy. The sample in this study was taken using a random sampling technique based on the area (random cluster sampling), which was carried out from October 2019 to December 2019.

The data used in this study are primary data through observations of the three agents. The sampling technique used in this study is the incidental sampling technique, which is a sampling technique based on chance; that is, anyone who happens to meet the researcher can be used as a sample if it is considered that someone who happens to be met is suitable as a data source, (Sugiono, 2012). As well as secondary data in the form of 3 months of sales data from the three brands of detergent. The data analysis used in this study was the method Analysis of Variance Two(ANOVA)with a value of $\alpha=0.05$. There are several steps to perform the two-way ANOVA test with interactions: (1) determining the hypothesis, (2) determining the real level. (3) determine the test area. (4) determine the ANOVA table.
Based on the research objectives, the hypotheses of this study are as follows;

$\mathrm{H}_{1}$ : sales volume of the three brands of detergent is the same

$\mathrm{H}_{\mathrm{a}}$ : sales volume of 3 brands of detergent is not the same

$\mathrm{H}_{2}$ : sales volume is the same every day

$\mathrm{H}_{\mathrm{a}}$ : daily sales volume is not the same

$\mathrm{H}_{3}$ : there is an effect of brand image on sales volume per day

$\mathrm{H}_{\mathrm{a}}$ : there is no influence on brand image to the volume of sales per day.

Following is the equation used in calculations other than using SPSS. The equation for the sum of the squares of the rows

$$
J K B=\sum \frac{T j^{2}}{k \cdot n}-\frac{T^{2}}{b \cdot k \cdot n}
$$

The equation for the sum of the squares of the columns.

Equation of total sum of squares

$$
J K T=\sum X i j^{2}-\frac{T^{2}}{b \cdot k \cdot n}
$$

Equation of sum of squares of interaction

$$
J K I=\sum \frac{T i j^{2}}{n}-\frac{T j^{2}}{k \cdot n}-\frac{T i^{2}}{b \cdot n}+\frac{T^{2}}{b \cdot k \cdot n}
$$

Equation of number of squares of error

$$
J K E=J K T-J K K-J K B-J K I
$$

After the researcher gets the value of each of the squares, the researcher can look for the results of the average quadratic equation, namely $\mathrm{S} 1, \mathrm{~S} 2$, $\mathrm{S} 3$, and S4.

$$
\begin{aligned}
& S 1^{2}=\frac{J K B}{b-1} \\
& S 2^{2}=\frac{J K K}{k-1} \\
& s 3^{2}=\frac{J K I}{(b-1)(k-1)} \\
& s 4^{2}=\frac{J K E}{b k(n-1)}
\end{aligned}
$$

Then the researcher can find the value of each $\mathrm{f}$ count after getting the average square value. $\mathrm{F}$ count has each $\mathrm{f}$ table; the goal is to find out the results of the conclusion of the hypothesis that the 
researcher will use to become a benchmark for making conclusions.

$$
\begin{aligned}
& f \text { hitung }(1)=\frac{S 1^{2}}{S 4^{2}} \\
& f \text { hitung }(2)=\frac{S 2^{2}}{S 4^{2}} \\
& f \text { hitung }(3)=\frac{S 3^{2}}{S 4^{2}}
\end{aligned}
$$

\section{RESULTS AND DISCUSSION}

The data on the sales of 3 detergent products at different food stall agents are presented in Table 1.1, which shows that from the two-way ANOVA test results, the f count $(1)<\mathrm{f}$ table is $0.027<2.48$ then $\mathrm{H} 1$ is accepted, thus sales volume 3 brands of detergent per day is the same. Whereas for hypothesis $2(\mathrm{H} 2)$, it is obtained that the value of $\mathrm{f}$ count (2)> f table is 9,124>3.26, then $\mathrm{H} 2$ is rejected. Thus the sales volume per product of 3 brands of detergent is not the same. Then the results obtained f count $(3)<f$ table, namely $0.815<2.11$, then $\mathrm{H} 3$ is accepted, which states the influence of brand image on sales volume per day.

Table 1.1. 2-way ANOVA with interactions.

\begin{tabular}{|l|l|l|l|l|}
\hline Varians & $\begin{array}{l}\text { Sum of } \\
\text { squares }\end{array}$ & $\begin{array}{l}\text { Mean of } \\
\text { square }\end{array}$ & fo \\
\hline Rows & 29.722 & 5 & 3.954 & 0.007 \\
\hline Coloum & 3987.11 & 2 & 1328.03 & 9.124 \\
\hline Interactions & 296.666 & 10 & 118.667 & 0.815 \\
\hline Error & 1310 & 36 & 145.556 & \\
\hline Totals & 5623.5 & 2 & & \\
\hline
\end{tabular}

Thus the causal factors for the sale of each product are not the same because they are influenced by the brand image, price, distribution, and promotion of each of the detergent production companies. Brand image is one of the important things that consumers take into account in making purchasing decisions. After making a purchase, brand image is only understood by consumers and is by their experience but does not directly determine whether the consumer will make a purchase decision. This finding can also be supported by Tjiptono (2011) that brand image (Brand imagery) involves the extrinsic properties of a product or service, namely the brand's ability to meet customers' psychological or social needs.
Brand imagery can be formed directly (through consumer experience and contact with products, brands, target markets, or usage situations) and indirectly (through advertisements and word of mouth communication).

Table 1.2. Comparison of Anava Test

\begin{tabular}{|c|r|r|r|c|c|}
\hline Model & $\begin{array}{c}\text { Sum of } \\
\text { square }\end{array}$ & Df & Mean square & F & Sig. \\
\hline 1. Regression & 184.267 & 4 & 46.067 & 16.161 & $.000 \mathrm{a}$ \\
\hline Residual & 259.389 & 91 & 2.85 & & \\
\hline Total & 443.656 & 95 & & & \\
\hline
\end{tabular}

Based on Table 1.2 above, the ANOVA test or $\mathrm{F}$ test results in a value of Fhitung 16.161 while Ftable is 2.31 (nk-1 error 5\%) so that $\mathrm{H} 3$ is accepted $\mathrm{Ha}$ is rejected and that means brand image influences consumers to buy so that sales volume to increase. According to Kotler and Keller (2012), "Brand Image is the public's perception of the company or its products." Meanwhile, according to Tjiptono (2011), "brand image is a description of associations and consumer beliefs about a particular brand. Meanwhile, the association is an attribute in the brand and has a level of strength". According to Kotler and Armstrong in the JRMB journal (2018), product quality is "one of the main positionings means for marketers." With good product quality, it will be able to provide its value and differentiate it from other products.

In addition, the most frequent factor that causes consumers to buy a product is the selling price of the product. Because the price is something that consumers pay attention to because the lower the price of a product, the higher the consumer who wants to buy, conversely the higher the price, it can be said that the lower the consumer who wants to buy, and also the affordable price also competes with competitors as well. Very influential on consumer purchasing decisions. This finding is also supported by Muslichah et all (2011) and Miftah (2018) that the prices of competitors affect the level of demand offered, so that competitors' prices must be taken into account in the pricing process.

According to Sunyoto (2012) distribution channel is a structure of organizational units within the company and outside the company consisting of agents, dealers, wholesalers, and retailers, through a marketed commodity, product, or service. Good product distribution can increase a sense of trust in certain products so that a large number of distributions of the three detergent brands in stores makes consumers not hesitate. In addition, promotion is one of the variables in the marketing 
mix that is very important for companies to implement in marketing products (Sunyoto, 2012). Promotional activities function as a means of communication between companies and consumers and as a tool to influence consumers in purchasing activities or using products according to their needs and desires.

Brand image, price, distribution, and promotion are variables that consumers pay attention to before making a purchase decision (Sunyoto, 2012). Brand image is the first thing that is considered when consumers come to the shopping center, and this is influenced by the experience of using the product or the indirect influence of promotion and brand strength. Kotler and Lane (2012) state that brand image is a consumer's hidden vision and belief, as a reflection of associations held in consumers' memories.

\section{Conclussions}

Based on the analysis of the research and discussion that has been carried out, it can be concluded that the sales volume of three brands of detergent per day is the same, the sales volume per product is not the same, and the influence of brand image on the sales volume of the three brands. In addition, the results of this study are taken into consideration for the company to build a brand image so that the optimal sales of these products are optimal.

In the next research, the researchers should add variables and the number of agents more and time in observation. So that it is expected to get more good research results. 


\section{REFERENSI}

Anwar, Gulzar, Sohail, Akram (2011), Impact of brand image, trust and affect on consumer brand extension attitude: the mediating role of brand loyalty. International Journal of Economics and Management Sciences. Vol. 1, No.5, , pp. 73-79.

El Fikri Miftah, S.E., M.Si. (2018). Analisis Citra Merek, Harga, Distribusi dan Promosi Terhadap Keputusan Pembelian Produk Sunlight Oleh Konsumen Rumah Tangga Di Kota Medan (Studi Kasus Di Kecamatan Medan Polonia). Jurnal Manajemen Tools, 10(2) ISSN : 2088-3145.

Erma Widiana Muslichah, Rusnawati Endah. ( 2011). Pengaruh Ekuitas Merek,Kualitas Produk dan Penjualan Perorangan Terhadap Keputusan Pembelian Produk Maspion di Desa Seruni Gedangan Sidoarjo. Surabaya : e-Jurnal Manajemen Kinerja.

Hartini , Sri. Pengembangan Kualitas Produk dan Kinerja Bisnis, Jurnal Manajemen dan Kewirausahaan. Vol.14,No.1. 2012.

Kalieva. 2015. Development of Territory Brand Image: The Marketing Aspect. Review of European Studies. Vol. 7, No.2; 23-27.

Kotler dan Keller. 2012. Marketing Management. New Jesey: Pearson Education Limited.

Kotler \& Amstrong. 2014. Principles of Marketing. New Jersey: Pearson Education Limited.

Lee , James, Kim (2014). A Reconceptualization of Brand Image. International Journal of Business Administration. Vol. 5, No. 4; 1-11.

Maurya and Mishra (2012). What is a brand? A Perspective on Brand Meaning. European Journal of Business and Management. Vol 4, No.3, 122-134.

Morhart, Malär, Guèvremont. 2014. Brand authenticity: An integrative framework and measurement scale. Journal of Consumer Psychology, 25(2).

MSG (2013). Management study guide, MSG 2013, Brand image. [21 March 2020] Available on the Internet: <URL: http://www.managementstudyguide.com/brand-image.htm >

Sugiyono. 2012. Metode Penelitian Bisnis. Bandung: Alfabeta.

Sugiyono. 2017. Metode Penelitian Kuantitatif, Kualitatif, dan R\&D. Bandung: Alfabeta.

Sunyoto, D. 2012. Dasar-Dasar Manajemen Pemasaran (Konsep, Strategi, dan Kasus). Jakarta: Buku Seru.

Tjiptono, Fandy dan Gregorius Chandra. 2016. Manajemen Pemasaran. Yogyakarta: Andi.

Winarso. 2012. Pengaruh Nilai Pelanggan dan Citra Merek serta Hambatan Berpindah terhadap Kepuasan dan Loyalitas Pelanggan Maskapai Penerbangan Lion Air di Bandara Internasional Sepinggan Balikpapan. Surabaya: Program Pascasarjana Universitas Airlangga. 